\title{
PENINGKATAN HASIL BELAJAR MATEMATIKA MELALUI MODEL QUANTUM TEACHING SISWA SMP NEGERI 10 SAMARINDA
}

\author{
Yunita Anggraeni Sari ${ }^{1)}$ \\ Abdul Basir Abbas ${ }^{2)}$ \\ Azainil $^{3)}$ \\ 1), 2), 3) Program Studi Pendidikan Matematika \\ Email: ${ }^{1)}$ yuansa93@gmail.com
}

\begin{abstract}
ABSTRAK
Penelitian ini adalah penelitan tindakan kelas dengan tujuan untuk meningkatkan hasil belajar matematika siswa kelas VII-I SMP Negeri 10 Samarinda melalui model Quantum Teaching pada materi pokok sudut dan garis-garis sejajar. Subjek penelitian ini adalah siswa kelas VII-I dan objek penelitian adalah model quantum teaching. Peneliti sebagai pelaksana pembelajaran sedangkan guru sebagai observator guru matematika. Teknik pengumpulan data dengan dokumentasi, observasi, tugas dan tes. Penelitian dilaksanakan dalam 3 siklus. Teknik analisis yang digunakan adalah teknik analisis kualitatif untuk menganalisis hasil observasi dan teknik kuantitatif untuk menganalisis tugas dan tes yang sesuai dengan indikator peningkatan yang telah ditentukan. Nilai hasil belajar diperoleh dari nilai tugas dan nilai tes hasil belajar tiap siklus. Nilai rata-rata ulangan harian pada materi himpunan dijadikan sebagai nilai dasar pada siklus I, yaitu 26,83 menjadi 72,97 dengan persentase ketuntasan sebesar 72,22\%. Dari siklus I ke siklus II mengalami peningkatan dari 72,97 menjadi 75,11 dengan persentase ketuntasan 75\%. Demikian juga dari siklus II ke siklus III mengalami peningkatan nilai rata-rata hasil belajar 75,11 menjadi 76,43 dengan persentase ketuntasan 83,33\%. Aktivitas guru pada siklus I dinilai cukup, siklus II dan III dinilai baik. Aktivitas siswa pada siklus I, II, dan III berturut-turut dinilai kurang, cukup dan baik.
\end{abstract}

Kata kunci: Peningkatan Hasil Belajar, Pembelajaran, Quantum Teaching.

\begin{abstract}
This research is a classroom action research with the aim of improving the mathematics learning outcomes of grade VII-I students of SMP Negeri 10 Samarinda through the Quantum Teaching model on the subject matter of angles and parallel lines. The subjects of this research were students of class VII-I and the research object was the quantum teaching model. The researcher acts as the learning implementer while the teacher is the mathematics teacher's observator. Data collection techniques with documentation, observation, assignments and tests. The research was conducted in 3
\end{abstract}


cycles. The analysis technique used is qualitative analysis techniques to analyze the results of observations and quantitative techniques to analyze assignments and tests in accordance with predetermined indicators of improvement. The value of learning outcomes is obtained from the value of the assignment and the test scores of learning outcomes for each cycle. The average value of daily tests on the set material was used as the basic value in the first cycle, namely 26.83 to 72.97 with a completeness percentage of $72.22 \%$. From cycle I to cycle II it increased from 72.97 to 75.11 with a completeness percentage of $75 \%$. Likewise, from cycle II to cycle III, there was an increase in the average value of learning outcomes from 75.11 to 76.43 with a percentage of $83.33 \%$ completeness. Teacher activity in cycle I was considered adequate, cycles II and III were considered good. Student activities in cycles I, II, and III were deemed insufficient, sufficient and good, respectively.

Keywords: Improvement of Learning Outcomes, Learning, Quantum Teaching

\section{PENDAHULUAN}

Kemajuan suatu bangsa salah satunya ditentukan oleh perkembangan pendidikan bagi anak bangsa itu. Kemajuan dalam satuan waktu jangka panjang akan dapat memprediksi kualitas bangsa pada sekian puluh tahun ke depan. Oleh sebab itu, pendidikan merupakan aspek penting yang perlu diperhatikan.

Salah satu masalah yang dihadapi dunia pendidikan kita adalah masalah lemahnya proses pembelajaran. Dalam proses pembelajaran, anak kurang didorong untuk mengembangkan kemampuan berpikir. Proses pembelajaran di dalam kelas diarahkan kepada kemampuan anak untuk menghafal informasi tanpa dituntut untuk memahami informasi yang diingatnya itu untuk menghubungkannya dengan kehidupan sehari-hari. Akibatnya, ketika anak didik kita lulus dari sekolah, mereka pintar secara teoritis, tetapi mereka miskin aplikasi (Sanjaya, 2011:1).

Perkembangan remaja adalah suatu masa di mana anak ingin menentukan jati dirinya dan memilih kawan akrabnya. Di dalam proses penyesuaian diri anak remaja, kemampuan intelektual dan emosional mempunyai pengaruh yang kuat. Saling pengertian akan kekurangan masing-masing dan upaya menahan sikap menonjolkan diri (mendominasi) diperlukan tindakan intelektual yang tepat dan kemampuan menyeimbangkan pengendalian emosional. Pola dan cara berpikir remaja cenderung mengikuti orang dewasa, karena itu, remaja sudah dapat memecahkan masalah yang kompleks secara rasional. Karakteristik siswa (remaja) tersebut menuntut guru untuk dapat menerapkan model pembelajaran aktif dan kreatif, model pembelajaran yang memperhatikan perbedaan individual, memberikan kesempatan kepada siswa untuk belajar bekerjasama dan bertanggung jawab, selain memperhatikan keberhasilan produk (hasil belajar siswa) tentunya. Meskipun diakui bahwa remaja masih belum mampu menguasai fungsi fisik maupun psikisnya, mereka butuh akan

82 Peningkatan Hasil Belajar Matematika Melalui Model Quantum Teaching Siswa Kelas VII-I SMP Negeri 10 Samarinda

Yunita Anggraeni Sari - Abdul Basir Abbas - Azainil 
pengakuan dan penghargaan bahwa mereka telah mampu berdiri sendiri, mampu melaksanakan tugas-tugas seperti yang dilakukan orang dewasa, dan dapat bertanggung jawab atas sikap perbuatan yang dikerjakannya (Djamarah, 2008:141)

Salah satu karakteristik matematika adalah memiliki objek kajian abstrak. Sifat abstrak ini menyebabkan banyak siswa yang mengalami kesulitan dalam matematika. Berdasarkan hasil wawancara dengan guru bidang studi matematika di SMP Negeri 10 Samarinda yang dilakukan oleh penulis didapatkan bahwa nilai matematika siswa masih tergolong rendah. Hal ini dapat dilihat dari nilai ulangan harian pada materi pokok himpunan di kelas VII, dan banyaknya siswa yang harus mengikuti remidi karena nilai ulangannya tersebut masih di bawah standar ketuntasan belajar matematika di sekolah tersebut.

Siswa kelas VII-I semester I di SMP Negeri 10 Samarinda tahun ajaran 2014/2015 pada materi pokok himpunan, lebih dari $80 \%$ siswa yang tidak mencapai KKM (kriteria ketuntasan minimal) yaitu 75. Hal ini dikarenakan selama proses belajar mengajar di kelas tersebut, siswa bersikap pasif dan rasa ingin tahu siswa tergolong rendah bahkan hampir tidak ada, guru cenderung menggunakan metode ceramah sehingga siswa hanya mendengarkan materi yang disampaikan guru tanpa adanya berpikir kritis ataupun sifat aktif pada siswa. Selain itu siswa kurang berkomunikasi untuk menyampaikan pendapatnya baik kepada guru maupun kepada temannya. Maka perlu model quantum teaching, dimana siswa dibawa ke dunia kita, dan antarkan dunia kita ke dunia mereka untuk menciptakan lingkungan belajar yang efektif, dengan cara menggunakan unsur yang ada pada siswa dan lingkungan belajarnya melalui interaksi yang terjadi di dalam kelas. Quantum teaching merupakan suatu proses pembelajaran dengan menyediakan latar belakang dan strategi untuk meningkatkan proses belajar mengajar lebih menyenangkan. Cara ini memberikan sebuah gaya mengajar yang memberdayakan siswa untuk berprestasi lebih dari yang dianggap mungkin karena proses belajar mengajar selalu berpusat pada apa yang masuk akal bagi siswa. Selain itu, akan menumbuhkan antusiasme siswa dan menimbulkan adanya kerjasama sehingga menciptakan tingkah laku dan sikap kepercayaan diri dalam diri siswa dan belajar akan terasa menyenangkan. Juga membantu guru memperluas keterampilan siswa dan motivasi siswa, sehingga guru akan memperoleh kepuasan yang lebih besar dari pekerjaannya.

Dengan menerapkan Quantum Teaching, maka dalam meningkatkan kualitas pembelajaran Matematika di pendidikan dasar dapat tercapai. Dalam kegiatan belajar siswa, guru berperan sebagai penggerak atau pembimbing, sedangkan siswa berperan sebagai penerima atau yang dibimbing. Proses interaksi ini akan berjalan baik apabila siswa banyak aktif dibandingkan guru. Sehubungan dengan hal tersebut, dalam kesempatan ini akan dicobakan model Quantum Teaching untuk pembelajaran Matematika kelas VII SMP Negeri 10 Samarinda. 


\section{METODE PENELITIAN}

Jenis penelitian ini adalah Penelitian Tindakan Kelas (PTK) yang akan dilaksanakan dalam 3 siklus. Setiap siklus dilaksanakan sesuai dengan tiga kali pertemuan dan pada pertemuan terakhir di setiap siklus diberikan tes. Soal tes pada setiap siklus dibuat oleh peneliti berbentuk uraian. Tahapan pelaksanaan penelitian tindakan kelas dimulai dari perencanaan tindakan, lalu pelaksanaan, selanjutnya observasi, dan terakhir refleksi.

Penelitian ini dilaksanakan pada semester genap tahun ajaran 2014/2015. Tempat penelitian adalah kelas VII-I SMP Negeri 10 Samarinda. Subjek penelitian ini adalah seluruh siswa kelas yang berjumlah 36 siswa dan yang menjadi objek dalam penelitian ini adalah model pembelajaran quantum teaching. Pengumpulan data pada penelitian ini dilakukan dengan cara dokumentasi, observasi, tugas dan tes.

Analisis data yang digunakan adalah analisis kualitatif dan analisis kuantitatif. Pada penelitian ini, data yang dianalisis secara kualitatif adalah data hasil observasi berlangsungnya proses pembelajaran yang menerapkan model quantum teaching.

Pada penelitian ini data yang dianalisis secara kuantitatif adalah data nilai hasil belajar siswa. Sudijono (2006) menyatakan untuk mengetahui hasil belajar siswa, dilakukan dengan analisis terhadap data nilai tugas kelompok, nilai tugas individu dan nilai tes pada setiap siklus menggunakan Persamaan 1 dan Persamaan 2,

$$
\begin{gathered}
N K=\frac{N T+2 N A}{3} \\
N T=\frac{L T+P R}{2}
\end{gathered}
$$

dengan NK NA, LT, NT, dan PR berturutturut menyatakan nilai hasil belajar siswa pada setiap siklus, nilai tes akhir siklus, lembar tugas siswa, rata-rata nilai tugas, dan pekerjaan rumah.

Siklus dalam penelitian ini dihentikan jika telah memenuhi indikator sebagai berikut:

1. Siswa mencapai nilai Kriteria Ketuntasan Minimal (KKM) yaitu 75.

2. Apabila aktivitas guru dan aktivitas siswa dalam pembelajaran minimal berkategori baik yang diukur berdasarkan lembar observasi.

3. Tuntas secara klasikal, yaitu apabila minimal $80 \%$ siswa di kelas tersebut memperoleh nilai lebih dari atau sama dengan 75 .

\section{HASIL PENELITIAN DAN PEMBA- HASAN}

Nilai akhir hasil belajar matematika diperoleh dari rata-rata nilai tugas (lembar tugas dan PR) dan nilai tes setiap akhir siklus. Hasil penelitian terdiri dari hasil observasi aktivitas guru dan aktivitas siswa, serta hasil analisis data yang diperoleh pada saat penelitian berlangsung, yaitu dari siklus I, siklus II, dan siklus III. Sehingga hasil analisis dari keseluruhan siklus, baik dari hasil observasi maupun hasil belajar dapat dilihat pada Tabel 1 dan Tabel 2. 
Tabel 1. Hasil Observasi pada Siklus I, II dan III

\begin{tabular}{lcccccc}
\hline Tahapan & \multicolumn{3}{c}{ Aktivitas Siswa } & \multicolumn{3}{c}{ Aktivitas Guru } \\
& Siklus I & Siklus II & Siklus III & Siklus I & Siklus II & Siklus III \\
\hline Tumbuhkan & Kurang & Cukup & Baik & Cukup & Baik & Baik \\
Alami & Kurang & Cukup & Baik & Cukup & Cukup & Baik \\
Namai & Cukup & Baik & Sangat & Cukup & Baik & Baik \\
& & & Baik & & & \\
Demonstrasikan & Kurang & Cukup & Baik & Kurang & Cukup & Sangat \\
& & & & & & Baik \\
Ulangi & Cukup & Baik & Baik & Baik & Baik & Baik \\
Rayakan & Kurang & Baik & Sangat & Baik & Baik & Sangat \\
& & & Baik & & & Baik \\
\hline
\end{tabular}

Tabel 2. Hasil Belajar Matematika Siswa Siklus I, II, dan III

\begin{tabular}{lllcrr}
\hline Pembelajaran & Nilai Dasar & NT & NA & NK & Peningkatan \\
\hline Siklus I & 26.83 & 75.18 & 71.86 & 72.97 & $171.95 \%$ \\
Siklus II & 72.97 & 73.76 & 75.78 & 75.11 & $2.93 \%$ \\
Siklus III & 75.11 & 77.13 & 76.08 & 76.43 & $3.09 \%$
\end{tabular}

Permasalahan yang terjadi sebelum proses selama penelitian berlangsung. Setelah pembelajaran Quantum Teaching, yaitu siswa paham, kemudian guru memulai nilai matematika siswa tergolong rendah, pembelajaran sesuai dengan skenario yang dapat dilihat dari nilai ulangan pembelajaran serta rencana pembelajaran harian pada materi pokok himpunan yang yang telah dibuat. Kemudian pada kurang dari $80 \%$ siswa tidak mencapai pertemuan ketiga, peneliti memberikan nilai KKM di SMP Negeri 10 Samarinda tes akhir siklus I untuk mengetahui hasil yaitu 75 .

Perencanaan awal yang peneliti lakukan adalah membuat rencana pelaksanaan pembelajaran materi sudut dan garis-garis sejajar sesuai dengan silabus sekolah berdasarkan skenario. Peneliti melakukan pengelompokkan siswa agar kelompok yang terbentuk heterogen, maka siswa dikelompokkan berdasarkan nilai ulangan harian materi himpunan. Kemudian siswa berkumpul dengan kelompok masing-masing dan mendiskusikan lembar kerja yang telah dibagikan oleh guru. Pada awal pertemuan guru menjelaskan model quantum teaching yang akan digunakan belajar siswa.

Berdasarkan hasil observasi pembelajaran pada siklus I diketahui bahwa untuk aktivitas siswa secara keseluruhan dinilai masih kurang karena masih ada beberapa siswa yang asyik bercerita dengan teman kelompoknya pada saat guru menjelaskan materi. Selain itu rasa tanggung jawab terhadap tugas yang diberikan kepada kelompoknya masih sangat kurang, sebagian besar kelompok hanya didominasi oleh 1 orang dalam mengerjakan tugas dan anggota lainnya hanya menunggu jawaban dari teman kelompoknya. Sebagian besar siswa juga masih malu untuk bertanya 
apabila ada penjelasan guru yang masih kurang ia pahami. Sedangkan untuk aktivitas guru secara keseluruhan dinilai cukup, karena guru masih kurang dalam memberikan motivasi kepada siswa. Guru juga masih kurang dan belum proporsional dalam memberi kesempatan kepada siswa untuk maju mengerjakan soal. Serta kurang efisien dalam penggunaan waktu. Pada siklus I hasil belajar siswa mengalami peningkatan dari rata-rata nilai dasar 26,83 menjadi 72,97.

Berdasarkan observasi siklus I, diperoleh kemajuan-kemajuan berikut (1) siswa mulai tertarik dan lebih antusias dalam mengikuti kegiatan yang ada disetiap pembelajaran, (2) penjelasan materi yang disampaikan cukup jelas sesuai dengan tujuan pembelajaran dan (3) nilai hasil belajar matematika siswa pada siklus I mengalami peningkatan. Namun terdapat beberapa hambatan yang terjadi selama proses pembelajaran berlangsung antara lain (1) masih ada siswa yang belum aktif dalam bekerjasama pada saat diskusi kelompok, sedangkan yang bekerja hanya beberapa siswa dalam kelompoknya dan yang lainnya hanya menunggu jawaban, (2) belum ada siswa yang berani untuk bertanya apabila ada yang belum ia pahami, (3) perhatian guru masih terpusat pada beberapa kelompok dibagian depan saja, belum memberikan bimbingan kepada semua kelompok secara merata, (4) karena banyak siswa yang asyik bercerita dan tidak mengerjakan tugas dengan baik sehingga penggunaan waktu pembelajaran tidak efisien, (5) nilai hasil belajar matematika siswa belum mencapai
$80 \%$ diatas KKM, siswa yang mencapai yaitu $72.22 \%$ saja.

Berdasarkan hasil refleksi pada siklus I, maka dapat dilakukan beberapa perbaikan tindakan, yaitu:

(1) Guru lebih sering memperhatikan siswa yang duduk dibarisan belakang pada saat menjelaskan agar tidak ada lagi siswa yang bercerita dengan temannya. (2) Guru memberikan bimbingan yang merata kepada seluruh siswa dan tidak terfokus pada kelompok tertentu agar seluruh siswa memahami materi yang mereka pelajari. (3) Guru lebih tegas dalam menegur siswa yang asyik bercerita dengan teman sekelompoknya dan yang membuat suasana kelas menjadi gaduh. (4) Guru menekankan kepada siswa pentingnya kerjasama dalam kelompok agar tidak hanya didominasi oleh beberapa anggotanya saja. (5) Guru harus lebih proporsional dalam memberi kesempatan kepada siswa pada saat melaporkan hasil diskusi kelompoknya dan pada saat mengerjakan soal latihan didepan.

Berdasarkan hasil observasi pada siklus II diketahui bahwa untuk aktivitas siswa secara keseluruhan dinilai cukup. Pada siklus II, siswa sudah mulai melengkapi alat-alat pembelajaran, siswa sudah mulai merespon pertanyaan yang diberikan guru, beberapa siswa juga sudah mulai berani dalam memberikan pendapatnya dalam pembahasan. Siswa juga mulai berani untuk mengerjakan soal di depan kelas ketika ditunjuk oleh guru. Pada saat kerja kelompok, siswa mulai bekerjasama, meskipun demikian sebagian besar masih didominasi oleh siswa yang pandai saja. Untuk aktivitas 
guru secara keseluruhan dinilai baik karena guru mengorganisasikan semua kelompok untuk mengerjakan tugasnya sudah mulai merata dan sudah bisa mengatasi perilaku siswa yang tidak diinginkan. Namun masih kurang efisien dalam penggunaan waktu belajar. Pada siklus II hasil belajar siswa mengalami peningkatan dari rata-rata nilai dasar 72,97 menjadi 75,11.

Setelah selesai pembelajaran siklus II, peneliti bersama observator mendiskusikan hasil tindakan berdasarkan rekapitulasi hasil observasi, hasil belajar dan hal-hal yang telah dicapai pada siklus II untuk menentukan perbaikan pada siklus selanjutnya. Dari hasil observasi ternyata kemajuan-kemajuan yang diperoleh, yaitu: (1) siswa sudah mulai memperhatikan dan mencatat penjelasan guru, (2) siswa yang asyik bercerita sendiri sudah berkurang, (3) siswa berani maju untuk mengerjakan soal, (4) dalam kerjasama kelompok sudah mulai terlihat aktif walaupun sebagian masih didominasi oleh siswa yang pandai, dan (5) hasil belajar matematika siswa mengalami peningkatan.

Dari hasil observasi juga terdapat beberapa hambatan yang terjadi selama proses pembelajaran berlangsung antara lain: (1) masih ada siswa yang asyik cerita pada saat diskusi, tapi sebagian sudah mulai aktif terlibat dalam diskusi kelompok, (2) masih ada siswa yang malu ataupun takut saat melaporkan hasil diskusinya, sehingga masih didominasi oleh siswa yang pandai saja, (3) masih terdapat siswa yang memperoleh nilai dibawah KKM yaitu sebanyak 9 siswa dari 36 siswa, dengan kata lain 75\% siswa yang tuntas dan $25 \%$ yang tidak tuntas, sehingga tindakan pada siklus selanjutnya masih diperlukan.

Berdasarkan hasil diskusi pada siklus II, peneliti bersama-sama observator mempersiapkan rencana kegiatan yang akan dilakukan pada siklus III. Beberapa tindakan perbaikan yang harus dilakukan berdasarkan refleksi pada siklus II antara lain: 1) Guru lebih tegas lagi dalam menegur siswa yang bercerita pada saat proses pembelajaran berlangsung. 2) Guru lebih mengawasi keaktifan seluruh anggota kelompok dalam berdiskusi dan lebih membagi fokusnya ke seluruh kelas, tidak hanya pada kelompok tertentu saja. 3) Guru lebih memberikan kesempatan kepada siswa yang belum pernah mempresentasikaan hasil diskusi kelompoknya di depan kelas dan yang belum pernah mengerjakan soal latihan didepan kelas pada pertemuan sebelumnya.

Berdasarkan hasil observasi pada siklus III diketahui bahwa untuk aktivitas siswa secara keseluruhan dinilai baik. Pada siklus III, siswa sudah antusias dalam mengikuti pelajaran. Siswa memperhatikan penjelasan dari guru. Ketika guru memberikan pertanyaan, siswa aktif menjawab pertanyaan yang diberikan oleh guru. Dalam diskusi kelompok, siswa sudah bisa bekerjasama dalam mengerjakan tugasnya dan sudah tidak didominasi oleh siswa yang pandai saja. Untuk aktivitas guru secara keseluruhan dinilai baik, karena guru sudah memanfaatkan alat peraga. Dalam mengorganisasi dan membimbing semua kelompok untuk mengerjakan tugasmya 
juga sudah merata. Dalam memberikan kesempatan mempresentasikan hasil diskusi dan mengerjakan soal latihan didepan sudah proporsional. Pada siklus III hasil belajar siswa mengalami peningkatan dari rata-rata nilai dasar 75,11 menjadi 76,43 .

Setelah selesai pembelajaran siklus III, peneliti bersama observator mendiskusikan hasil tindakan berdasarkan rekapitulasi hasil observasi, hasil belajar dan hal-hal yang telah dicapai pada siklus III. Beberapa kemajuan yang terjadi setelah diberikan perbaikan tindakan dari hasil obervasi pada siklus sebelumnya antara lain (1) suasana kelas lebih terkendali dibandingkan dengan siklussiklus sebelumnya, (2) siswa sudah bisa saling kerjasama dan memiliki rasa tanggung jawab akan tugas kelompoknya, tidak hanya didominasi oleh siswa yang pandai saja dalam berdiskusi dan dalam melaporkan hasil diskusinya dan (3) persentase siswa yang nilai hasil belajar matematikanya diatas KKM mencapai $83,33 \%$ atau sebanyak 30 siswa dari 36 siswa. Dengan didasarkan pada hasil observasi dan analisis data pada siklus III telah tercapai dengan baik, peneliti dan observator sepakat untuk tidak melanjutkan tindakan pada siklus selanjutnya.

\section{KESIMPULAN}

Dari hasil penelitian tindakan kelas dan pembahasan dapat disimpulkan bahwa terjadi peningkatan hasil belajar setelah penerapan model Quantum
Teaching pada materi pokok sudut dan garis-garis sejajar di Kelas VII-I SMP Negeri 10 Samarinda tahun ajaran 2014/2015. Pada siklus I terjadi peningkatan hasil belajar dari rata-rata nilai dasar 26.83 menjadi 72.97 dengan rata-rata poin peningkatan sebesar 30.00 . Selanjutnya pada siklus II terjadi peningkatan hasil belajar dari rata-rata nilai akhir siklus I 72.97 menjadi 75.11 dengan rata-rata poin peningkatan sebesar 17.22. Terakhir pada siklus III terjadi peningkatan hasil belajar dari rata-rata nilai akhir siklus II 75.11 menjadi 76.43 dengan rata-rata poin peningkatan sebesar 16.39.

\section{DAFTAR PUSTAKA}

Djamarah, S. B. (2008). Psikologi Belajar. Jakarta: Rineka Cipta

Sanjaya, W. (2011). Strategi Pembelajaran; Berorientasi Standar Proses Pendidikan. Jakarta: Kencana Prenada Media Group.

Sudijono, A. (2006). Pengantar Evaluasi Pendidikan. Jakarta: PT Raja Grafindo.

Sudjana, N. (2009). Penilaian hasil proses belajar mengajar. Bandung: Remaja Rosdakarya 